\title{
Otra historia para otra psiquiatría
}

\section{Cristina Sacristán (DD https://orcid.org/0000-0002-9587-7096}

Instituto de Investigaciones Dr. José María Luis Mora, México csacristan@mora.edu.mx

Rafael Huertas, Otra historia para otra psiquiatría, Barcelona, Xoroi Edicions, 2017, 326 páginas.

Si todo buen libro de historia establece un vínculo con el presente, los textos de Rafael Huertas, reunidos en Otra historia para otra psiquiatría, reclaman este nexo desde dos ángulos que apuntalan esta obra. Por un lado, se trata de una historia que analiza las llamadas enfermedades mentales como construcciones históricas en diálogo con la clínica psiquiátrica y los dilemas actuales de la relación médico-paciente. La reflexión histórica sobre la concepción de la locura y el devenir del conocimiento psiquiátrico tiende una ruta para examinar, con la perspectiva de la larga duración, bajo qué presupuestos actúan hoy los profesionales de la salud mental en su labor cotidiana; adentrarse en el pasado para pensar el presente. En sentido inverso, la mirada a los tiempos pretéritos se sostiene desde una posición que anida en la necesidad “de acompañar y de propiciar el empoderamiento de las personas con sufrimiento psíquico” (p. 236). Por ello, articular esta otra historia no habría sido posible sin esa otra psiquiatría, cuyo quehacer busca un trato más cercano, humano y efectivo que trascienda la actual "cultura de la receta” (inmersa en una concepción meramente biológica de las enfermedades mentales) y

\section{(c) (1) (8)} No-Comercial 4.0 Internacional.

Secuencia. E-ISSN 2395-8464 http://secuencia.mora.edu.mx/

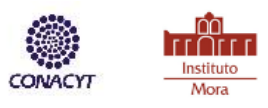


que abra un espacio a la escucha del paciente, en un claro intento por construir una relación más horizontal entre el saber del experto y la experiencia vital del enfermo. Así, historia crítica y clínica comprometida interactúan a lo largo de los ocho trabajos que, publicados en los últimos veinte años, se presentan ahora revisados y actualizados gracias a los buenos oficios de Rafael Huertas y de los directores de "La Otra psiquiatría”, colección en la que se edita este texto, José María Álvarez y Fernando Colina.

Como ambos afirman en el prólogo, el hilo conductor del libro teje en torno a la comprensión del sujeto de la locura, un sujeto que desde el oficio de la historia comenzó a ser revalorado hacia los años sesenta del siglo pasado en tanto agente transformador de la sociedad; propuestas como la historia desde abajo y la microhistoria tomaron distancia del paradigma estructuralista y pusieron en el centro del análisis la libertad de elección de los individuos. En el campo de la historia de la psiquiatría, el abordaje es más reciente; entre los años ochenta y noventa se alertó sobre la necesidad de considerar el punto de vista del paciente y recuperar sus experiencias para identificar qué significó estar loco o pasar por estar loco, enfoque que en este libro camina de la mano con la historia sociocultural de la enfermedad, en tanto atiende a los contextos donde se construyen las enfermedades, inscritas en el pensamiento psicopatológico de su época, pero sujetas a cambios sociales y culturales, de ahí su historicidad.

Ahora bien, Huertas se acerca al sujeto de la locura desde un espectro muy amplio de temas que abre varios frentes de reflexión y debate en torno a la historiografía (de la historia tradicional a la historia de la subjetividad), las fuentes (de los tratados de psiquiatría a las

\footnotetext{
${ }^{1}$ Silvia Díez, "Entrevista a José María Álvarez. Se han inventado trastornos mentales", Cuerpomente, https://www.cuerpomente.com/entrevistas/entrevista-jose-maria-alvarez-trastornos-mentales-inventados_4245 (consulta: 21 noviembre de 2019).
}

Secuencia. E-ISSN 2395-8464 
narrativas de los locos) y la epistemología (de la clínica de la mirada a la clínica de la escucha). Así, Huertas rescata del olvido, en el nacimiento del alienismo, al médico saboyano Joseph Daquin (1732-1815), figura ignorada por el alienismo francés y antecesor de Pinel en su reflexión médica y filosófica sobre el que más tarde se denominaría tratamiento moral. Como se sabe, el tratamiento moral abrevó en el filantropismo del Siglo de las Luces en el sentido de abogar por una terapéutica más humanitaria que reparara en las pasiones como causa de la locura, lo que no fue obstáculo para que Daquin, y después Pinel, se dieran a la búsqueda de la lesión anatómica, en tanto el cerebro permanecía como el asiento de la locura. Filosofía y medicina en los orígenes del alienismo, sitúan este texto en el debate sobre la causalidad moral (psicológica) de la locura y su soporte material en un órgano (el cerebro), entre optar por la "higiene del alma" (régimen de vida) o los agentes físicos para restablecer la salud.

Ciertamente, la mentalidad anatomoclínica ilustrada, que correlacionaba síntoma con lesión corporal, no encontró una respuesta fácil en el terreno de la medicina de la mente, donde la exploración médica llevó a recuperar las experiencias de los pacientes. Por ello, desde el primer tercio del siglo XIX arranca la construcción de una sintomatología de la subjetividad en ámbitos como la clínica de las alucinaciones, el análisis de las últimas voluntades de los suicidas, en las llamadas locuras parciales o mediante el estudio de los escritos de los locos, lo que lleva a Huertas, siguiendo a otros autores, a plantear la existencia de una "clínica de la escucha” desde los orígenes mismos del alienismo -mucho antes de Freud-, que busca interpretar lo que ellos expresan. Si en las salas de las autopsias los cadáveres de los alienados “permanecían mudos”, podía hacerse el esfuerzo de "leer en su pensamiento" (p.111). Se observa pues que, junto a la noción de la alienación mental como enfermedad del cuerpo, convive la búsqueda de métodos de exploración psicológica.

Secuencia. E-ISSN 2395-8464 
Tan actual como este tema es la discusión sobre la concepción unitaria de la enfermedad mental versus el paradigma de las enfermedades mentales. Para la primera, la "psicosis única” apela a una concepción antigua según la cual "las diferentes formas clínicas no serían auténticas entidades morbosas, sino fases sucesivas” de una patología única -la alienación mental-, fases o especies que se pueden presentar en un mismo individuo (p. 58). Frente a ella, la defensa de la pluralidad de las enfermedades mentales planteó el problema de su clasificación ante la imposibilidad de hacerlo por las alteraciones anatómicas del cerebro. Quedó entonces el recurso de construir una nosología por los síntomas, que finalmente triunfó y sigue vigente hasta el día de hoy. Esta consideración única o múltiple de la enfermedad mental remite a una discusión de gran calado al colocar al sujeto de la locura entre un modelo que “considera el síntoma de un modo mecanicista y biologicista, en la medida que lo hace responder a una función neuronal «estropeada» que hay que arreglar (curar) para que el síntoma (el déficit) desaparezca” y aquel que antepone la subjetividad del loco, donde "el síntoma será entendido como una formación defensiva, como un esfuerzo de autorreparación” (p. 92), clínica somaticista versus clínica de la subjetividad.

Contra la historia de los conceptos sin su debida contextualización, se lanza Huertas al analizar "las obsesiones antes de Freud”, en una lectura muy crítica de las continuidades en la historia cuando éstas se plantean de manera lineal y progresiva sin advertir cómo estos conceptos están atravesados por distintos paradigmas (psicodinámico, neuroanatómico, bioquímico, etc.) que en su momento y hoy derivaron y derivan en posicionamientos y terapéuticas muy diferentes y es aquí donde más sentido tiene señalar, como lo hace, que "lo bio en salud mental no es solo lo biológico, sino también lo biográfico” (p. 265), ese conjunto de elementos sociales y culturales que "envuelve" a los sujetos, pero no como "ruido de fondo”, sino como un espacio de significaciones que lo dotan de sentido. 
Huertas aborda también la incursión de la medicina de la mente en otras esferas como la del terreno judicial, con la complejidad que supuso para la incipiente psiquiatría la determinación de la locura criminal al apoyarse en sus inicios en la controvertida monomanía, diagnóstico con una evidencia muy débil, aunque maleable. Para el sujeto de la locura, el eximente o atenuante de responsabilidad penal eliminaba toda posibilidad de decisión sobre sus propios actos, el famoso "no ha lugar” del que Althusser es el ejemplo más paradigmático y que en el texto que nos ocupa se analiza como "responsabilidad subjetiva”. De igual manera, la patologización de la sexualidad convirtió al "perverso" en un enfermo que transgredía una doble norma, la moral y la natural, y para quien no se escatimaron las terapias más agresivas con el fin de devolverlo a la "normalidad", conformó la tríada vicio/delito/enfermedad que hoy podríamos enunciar como la peligrosidad del enfermo mental, de ninguna manera evidente.

El libro cierra con un ensayo historiográfico que recorre distintas aproximaciones a la historia de la psiquiatría: una historiografía tradicional internalista que busca la legitimación social y profesional del psiquiatra y de su ejercicio médico; una historiografía crítica de raigambres diversas, foucaultianas y no foucaultianas; una historia que coloca el lugar de enunciación en los subalternos, locos en este caso, con fuentes complejas pero no imposibles; y finalmente, una historia cultural de la subjetividad que da cabida a una historia intelectual de los conceptos psiquiátricos, una historia social de la profesión, una historia política que analiza los saberes y las prácticas psiquiátricas en relación con el poder político y una historia que considera la perspectiva del paciente. A practicar esta historia nos convoca este libro; a pensar la locura, más allá de su origen biológico, también. No podemos eludirlo.

Secuencia. E-ISSN 2395-8464 